Omni-Akuatika, 15 (2): 1-11, 2019
ISSN: 1858-3873 print / 2476-9347 online
Research Article
journal homepage: http://ojs.omniakuatika.net

\title{
Carbon Content In Macroalgae Species Against Temperature Regime
}

\author{
Tri Dewi Kusumaningrum Pribadi ${ }^{1}$, Ramdan Nurdiana ${ }^{1}$, Yudi Nurul Ihsan ${ }^{2, *}$ \\ ${ }^{1}$ Department of Biology, Universitas Padjadjaran, J. Raya Bandung-Sumedang km 21, Jatinangor 45363, \\ Indonesia \\ ${ }^{2}$ Department of Marine Science, Universitas Padjadjaran, Jl. Raya Bandung-Sumedang km 21, Jatinangor 45363, \\ Indonesia \\ ${ }^{*}$ Corresponding author: yudi.ihsan@unpad.ac.id
}

Received 5 August 2018; Accepted 9 October 2019; Available online 20 November 2019

\begin{abstract}
Temperature rise due to climate change has created environmental impacts on various ecosystems, including coastal areas. Temperature rise also affects plant metabolism, such as carbon uptake, where Macroalgae are the dominant community in the intertidal zone, and thus, potential to absorb carbon. A series of experiments on several dominant macroalgae species from the southern coastal area in West Java have been conducted to see the effect of temperature regime on their carbon content. The treatment of temperatures at $24,27,30$, and $33^{\circ} \mathrm{C}$ was carried out for 72 hours against 6 macroalgae species representing Chlorophyceae, Phaeophyceea and Rhodophyceae in order to investigate the carbon content. The results showed that the macroalgae of Phaeophyceae division absorbed higher carbon content in comparison to the macroalgae of the other divisions. The temperature significantly affecting chlorophyll was measured at testing temperature of $33^{\circ} \mathrm{C}$ against the tested species.
\end{abstract}

Keywords: carbon, intertidal zone, macroalgae, temperature

\begin{abstract}
ABSTRAK
Kenaikan suhu karena perubahan iklim global berdampak pada berbagai ekosistem, tanpa terkecualli daerah pesisir. Kenaikan suhu juga mempengaruhi metabolism tumbuhan, sebagai contah adalah penyerapan karbon seperti pada makroalga yang merupakan komunitas dominan pada zona intertidal. Serangkaian eksperimen terhadap makroalga yang dominan tumbuh di pesisir selatan Jawa Barat telah dilakukan untuk melihat efek dari perbedaan suhu terhadap kandungan karbon. Perlakuan suhu $24,27,30$, dan $33{ }^{\circ} \mathrm{C}$ terhadap 6 spesies makroalga yang mewakili divisi chlorophycea, phaeophyceae, dan rhodophyceae dalam durasi 72 jam, untuk mengetahui kandungan karbon dari masing-masing spesies yang diuji. Hasil yang diperoleh menunjukkan bahwa Phaeophyceae memiliki kandungan karbon yang lebih tinggi dibandingkan dengan dua divisi lainnya setelah perlakuan. Suhu $33{ }^{\circ} \mathrm{C}$ terbukti secara signifikan mempengaruhi kandungan klorofil pada semua spesies makroalga yang dicobakan.
\end{abstract}

Kata kunci: carbon, intertidal zone, macroalgae, temperature 


\section{Introduction}

The $\mathrm{CO}_{2}$ in atmosphere is significantly increasing from $280 \mathrm{ppm}$ to $404,96 \mathrm{ppm}$ in the past few decades, triggered by the industrial revolution (Eakin et al., 2008; NOAA, 2016). The Green House Effect has caused global temperature rise in seawater by $0.7^{\circ} \mathrm{C}$ in the ocean surface (Eakin et al., 2008) and may also affect the organisms, with no exception to macroalgae.

Macroalgae, in a positive way, contribute in reducing $\mathrm{CO}_{2}$ production released to the atmosphere and can significantly reduce global warming (Kaladharan et al., 2009). However, continuous global warming in seawater column will also affect macroalgal carbon uptake. Furthermore, almost every biological function (photosynthesis, respiration rate, growth, calcification level, nitrogen fixation, and reproduction) will be affected by chemical changes (Eakin et al., 2008), including the effect of Ocean Acidification (Porzio et al., 2017). Moreover, one of the consequences will also lead to the lost of biodiversity.

Macroalgae are distributed as cosmopolite in coastal areas and they play significant role in the primary production in mangrove ecosystem, seagrass beds, and coral reefs (Mineur et al., 2015). Along with seagrasses and mangroves, macroalgae contribute 50 per cent of the whole primary production on Earth (Beardall and Raven, 2004), and they also absorb carbon (Chung et al., 2011). Macroalgae contribute to up to $50 \%$ of the carbon fixation in this planet and cover as much as $71 \%$ carbon storage in the sea sediment. As the primary producer in the ocean, macroalgae have potential contribution in the carbon uptake and storage (Chung et al., 2011).

Less frequently work is also focusing on the species of macroalgae where they possess better ability in absorbing carbon than the other species in terms of temperature rise. This study attempts to fill the information gap concerning the carbon content and chlorophyll in macroalgal species as metabolism product due to the temperature rise.

\section{Materials and Methods}

Material of macroalgae taken from the southern part of West Java $\left(7.6408^{\circ} \mathrm{S}-7.6689\right.$ ${ }^{\circ} \mathrm{S}$ and $\left.107.6839^{\circ} \mathrm{E}-107.6967^{\circ} \mathrm{E}\right)$, includes Ulva fasciata, U. lactuca (Chlorophyceae), Sargassum binderi, Turbinaria conoides (Phaeophyceae), Gracilaria coronopifolia,
Acanthophora spicifera (Rhodophyceaea). The collected species were dominant species from each division found in the sampling location. The material was taken from the intertidal zone during low tide, cleaned up from epiphyte, and then stored in plastic jars to be kept in a cool storage prior to experiments. Acclimatisation was done in two steps. First step of acclimatisation was done in a fibre pond filled with seawater (filtered, 0.45 $\mu$ ) with aeration for 3 days under natural lighting in room temperature. The second step of acclimatisation for the temperature regime was done 48 hours with the same conditions of the initial acclimatisation, except for the temperatures. Each temperature treatment is done in different aquarium with mixed macroalgae.

Material used for the experiments was $1 \mathrm{~g}$ macroalgae and each of 6 species. They were placed in a 250-ml beaker filled with filtered seawater $(0.45 \mu)$. Experiments were run for 72 hours under natural lighting with the materials exposed to temperature regimes of $24,27,30$, and $33{ }^{\circ} \mathrm{C}$ with the same procedure for each of the 3 replicates. Experiments were done without nutrient addition in order to explore the carbon content affected by different temperatures. Samples were taken after 24, 48, and 72 hours of experimental periods for the Carbon and pigments analyses (chlorophyll). The percentage of Carbon changes was defined using the formula below:

$$
\left(\mathrm{C}_{\text {initial }}-\mathrm{C}_{\text {Final }}\right)
$$

Chlorophyll quantity is calculated using the formula by Arnon (1949).

Measurement of a sample ( $\mathrm{A}=\mathrm{absorbance})$

$$
\begin{gathered}
\text { Chlorophyll-a }\left(\mathrm{mg}^{-1} \mathrm{~g}^{-1} \mathrm{FW}\right)=0.0127 \mathrm{~A}_{663^{-}} \\
0.00269 \mathrm{~A}_{645}
\end{gathered}
$$

Results were then statistically analysed using software IBM SPSS version 2.2 to measure the significant values.

\section{Results and Discussion}

In general, carbon content found during the 72-hour experimental period showed general pattern of a slight decrease, except for Turbinaria conoides. Macroalgae from Phaeophyceae, $S$. binderi and $T$. conoides, showed higher initial carbon content in comparison to other tested species in this study. In comparison to other 
species (Fig. 1), the highlight results were showed by Phaeophyceae, with no significant difference $(F=0.06 ; p=0.1)$ in its carbon content for all temperature treatments.

Phaeophyceae showed better performance in absorbing carbon content at testing temperatures of 30 and $33{ }^{\circ} \mathrm{C}$, especially for $T$. conoides (Fig.1d). Results of $T$. conoides and $S$. binderi showed a surge of carbon content in day 48 and 72 , while the others showed a decrease. This result was also in line with the final carbon content, which showed a high difference between initial and final results (Fig. 2).

In general, Carbon content of macroalgae showed a decrease in most species, except for $T$. conoides at a temperature of $30{ }^{\circ} \mathrm{C}$ and $\mathrm{G}$. coronopifolia at a temperature of $24{ }^{\circ} \mathrm{C}$. Generally, T. conoides and S.binderi (Phaeophyceae) had lower decrease in carbon content. Division wise, the highest decrease in carbon content was shown by Chlorophyceae (U.lactuca and U. fasciata), Rhodophyceae (G. coronopifolia and $A$. spicifera), and Phaeophyceae ( $S$. binderi and $T$. conoides), each respectively (Fig. 2).

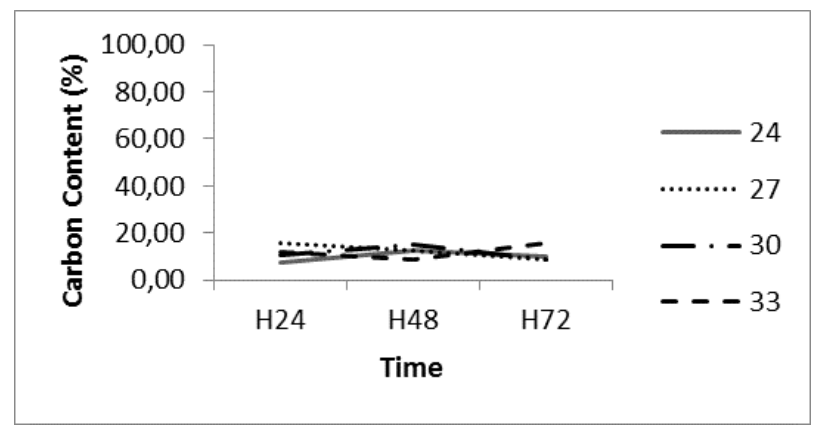

(a)

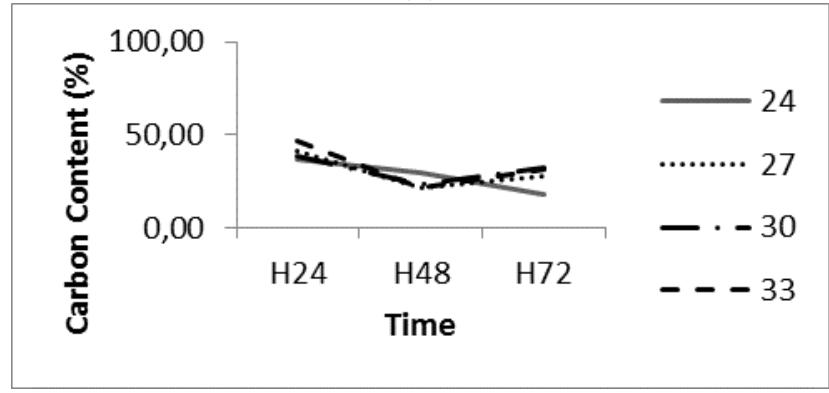

(c)
Generally, chlorophyll content in the final results showed a decreasing pattern in all species being tested $(F=0.00, p=0.00)$ for the individual macroalgae exposed at a temperature of $33{ }^{\circ} \mathrm{C}$ (Fig. 3). Different results however were shown by individuals exposed at lower temperatures of 24,27 and $30{ }^{\circ} \mathrm{C}$ in each species. The chlorophyll content significantly affected by all temperature treatments were $U$. lactuca $(F=0.01, p \leq 0.05)$ and $U$. fasciata $(F=$ $0.01, p \leq 0.02$ ) (Chlorophyceae).

Final chlorophyll content showed similar results in all species of individuals exposed at a temperature of $33{ }^{\circ} \mathrm{C}$ (Fig. 4). Individuals of all macroalgae species exposed at a temperature of $33{ }^{\circ} \mathrm{C}$ showed lower chlorophyll content in comparison to other individuals exposed at lower temperatures $\left(24,27\right.$, and $\left.30{ }^{\circ} \mathrm{C}\right)$. Final chlorophyll content of the species Rhodophyceae (G. coronopifolia and $A$. spicifera) relatively remained the same in individuals exposed at a lower temperature range after a 72-hour experimental period, while other species showed slight fluctuation among temperature treatment.

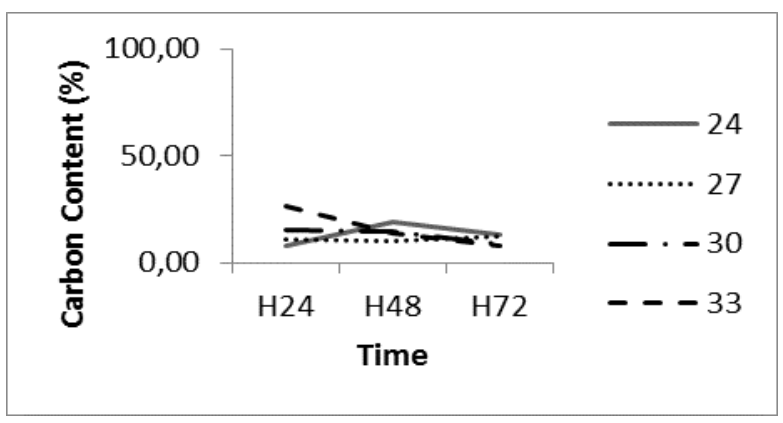

(b)

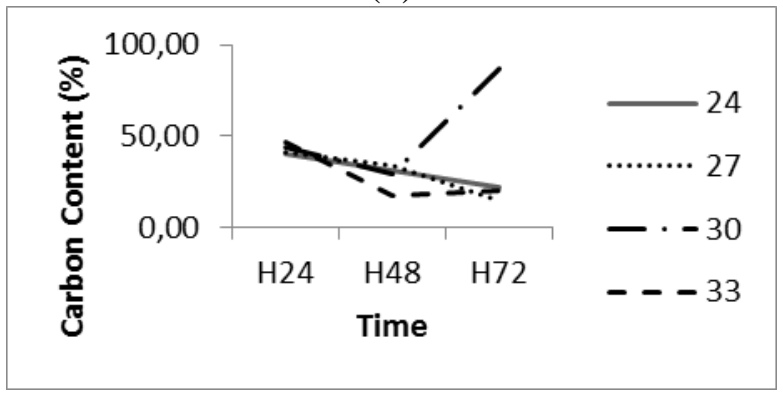

(d) 


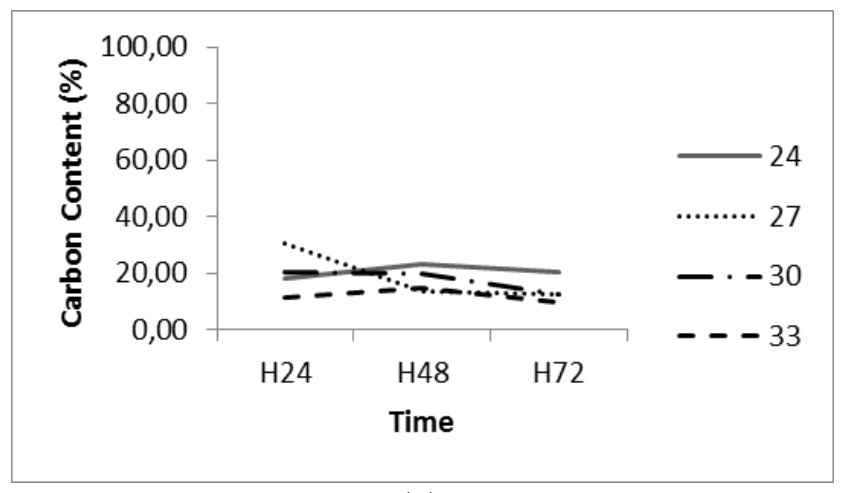

(e)

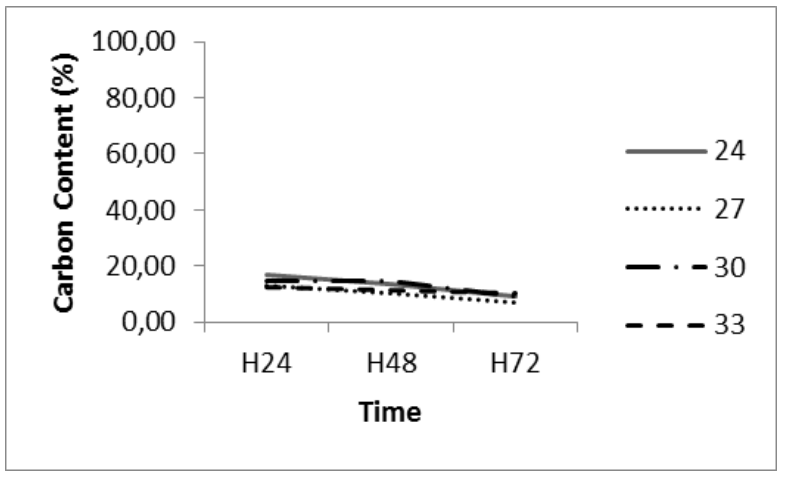

(f)

Figure 1. Content of Carbon (\%) from 6 macroalgae species: (a) U. lactuca; (b) U. fasciata; (c) S. binderi; (d) T. conoides; (e) G. coronopifolia; (f) A. spicifera, at testing temperatures of 24, 27, $30,33^{\circ} \mathrm{C}$ during the 72 -hour experimental period.

In this study, results generally showed that species of macroalgae from Chlorophyceae and Rhodophyceae performed lower absorbance of carbon content after being exposed at high temperatures. On the contrary, the carbon content of Phaeophyceae ( $S$. binderi and $T$. conoides) showed a slight decrease after a 72hour temperature treatment. This finding may indicate that macroalgae from Phaeophyceae can tolerate a wider temperature range.

The results of carbon content in this study was in line with Hurd et al. (2014), where the main factor of photosynthetic process was determined by nutrients and temperatures, thus would affect the carbon uptake and storage in macroalgae. Macroalgae need inorganic carbon, ionic mineral, and light for their growth, so the limitation on one of these factors will inhibit its metabolism, including carbon uptake. The amount of carbon decrease in most species indicated a disturbance caused by a temperature rise, with the exception of $T$. conoides that showed different results. The high carbon content in $T$. conoides, primarily in the treatment at testing temperatures of 30 and $33^{\circ} \mathrm{C}$ indicated that this species has the ability to uptake carbon in high temperature, even with no additional nutrient in the media.

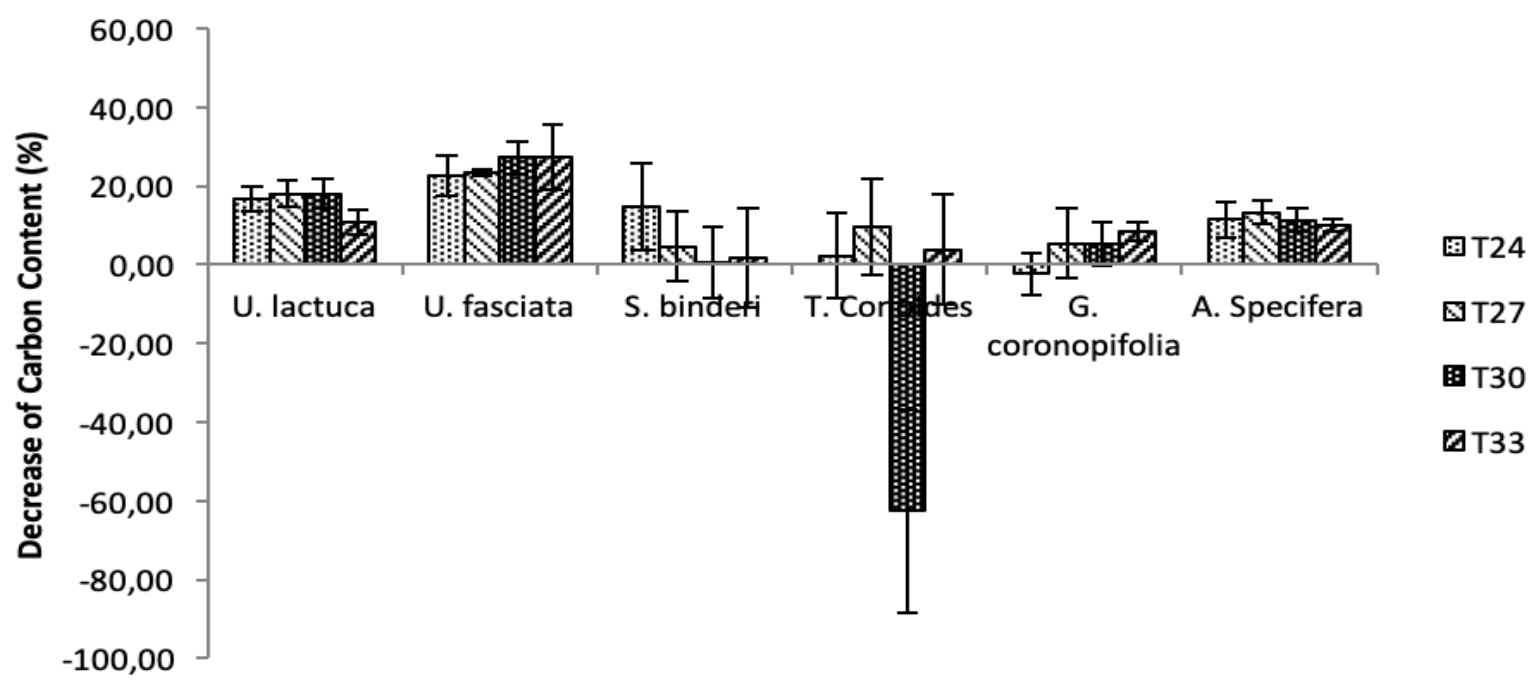

Figure 2. Decrease of Carbon content changes shown in percentage (\%) from 6 macroalgae species at testing temperatures of $24,27,30,33^{\circ} \mathrm{C}$ after a 72 -hour experimental period. 


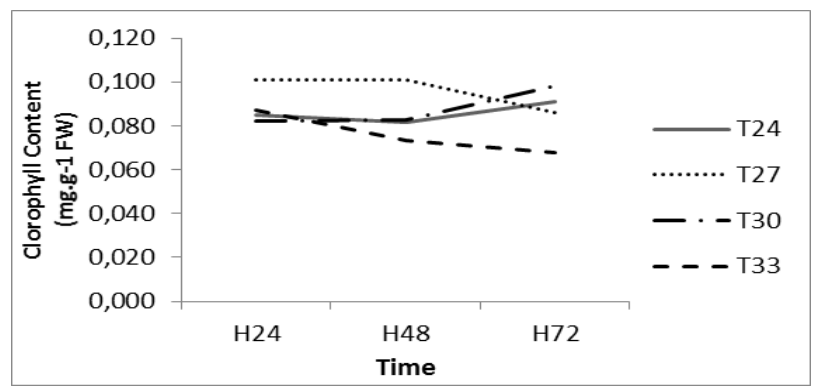

(a)

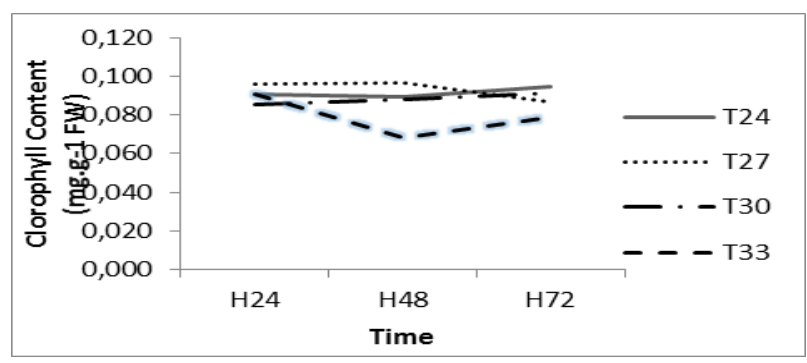

(c)

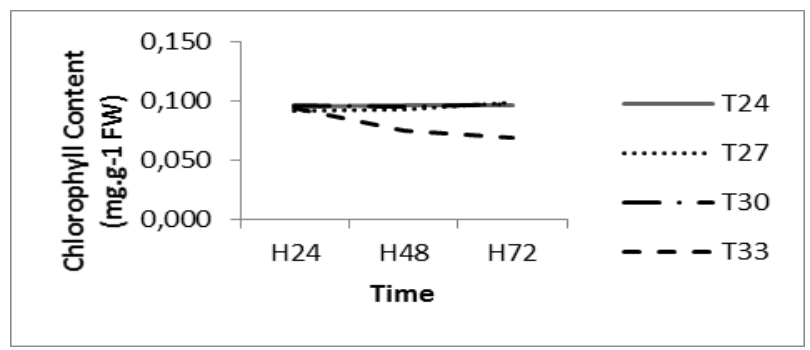

(e)

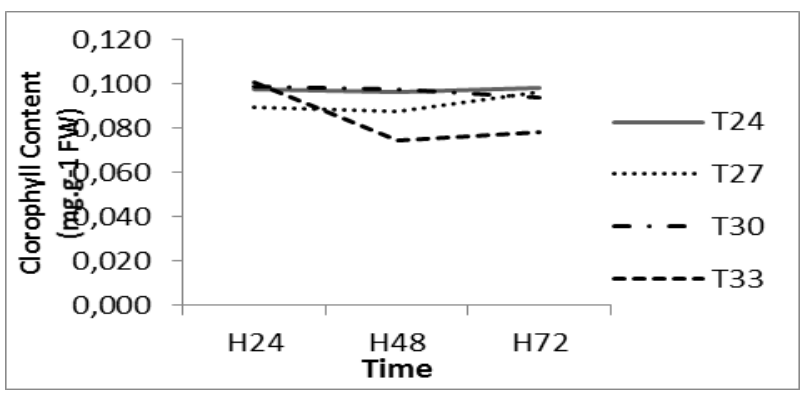

(b)

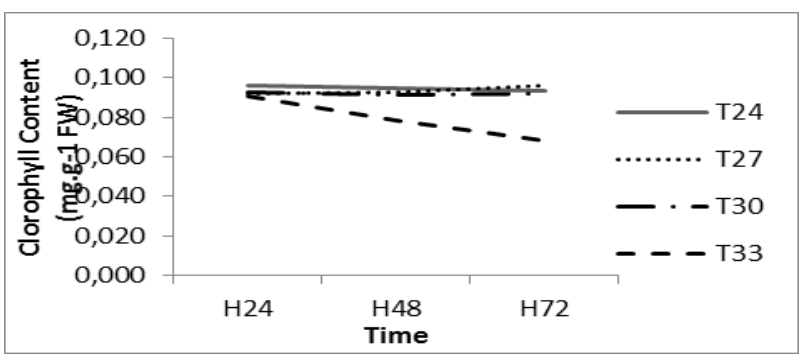

(d)

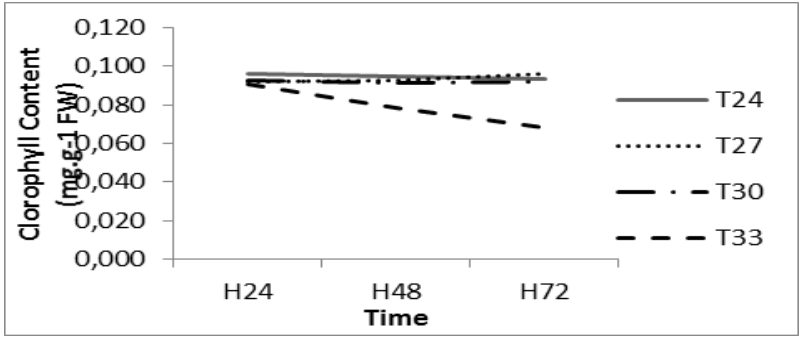

(f)

Figure 3. Content of chlorophyll (mg.g ${ }^{-1} \mathrm{FW}$ ) in 6 macroalgae species: (a) U. lactuca; (b) U. fasciata; (c) S. binderi; (d) T. conoides; (e) G. coronopifolia; (f) A. spicifera, at testing temperatures of 24, 27, 30, 33 ${ }^{\circ} \mathrm{C}$ during a 72 -hour experimental period.

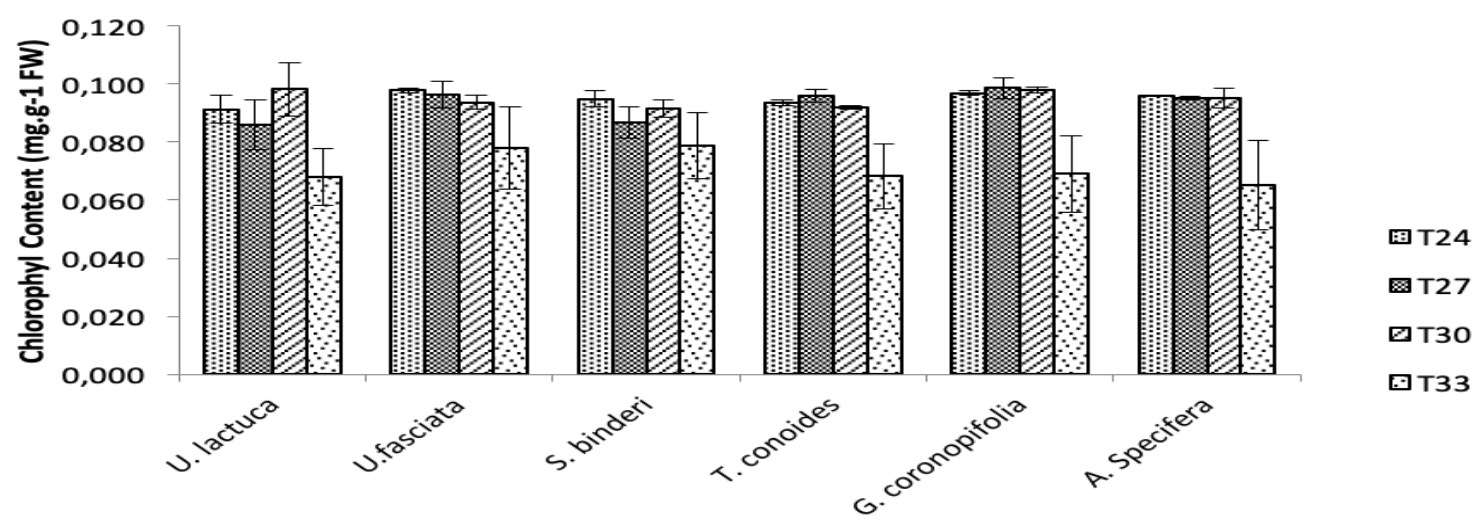

Figure 4. Final content of chlorophyll $\left(\mathrm{mg} \cdot \mathrm{g}^{-1} \mathrm{FW}\right)$ in 6 macroalgae species at testing temperatures of 24 , $27,30,33^{\circ} \mathrm{C}$ during the 72 -hour experimental period. 
Contrary to higher temperature treatments, different results were shown by $G$. coronopifolia, which experienced low carbon content decrease in the individuals exposed at a temperature of $24{ }^{\circ} \mathrm{C}$, showing that the temperature of $24{ }^{\circ} \mathrm{C}$ did not even affect the carbon content in $G$. coronopifolia. This result differed from the finding stated by Esteves et al. (2004) where in the research, Gracilaria sp. showed the highest carbon content after being exposed at a temperature of $30{ }^{\circ} \mathrm{C}$. These different results may presumably be due to the presence of nutrient addition. This assumption is also strengthened by the data source stating that the fast growing macroalgae like Gracilaria are positively affected by nutrient availability (Fernand et al., 2017; Monteiro, 2014). No nutrient supply during the experiments was estimated to be the cause of low carbon content.

The results of carbon content are consistent with the chlorophyll results. All species suffered from the high temperature in terms of chlorophyll content. The chlorophyll contents in all macroalgal species being tested were mostly affected at a temperature of $33^{\circ} \mathrm{C}$. At testing temperatures of 24,27 , and $30^{\circ} \mathrm{C}$, chlorophyll content of $G$. coronopifolia and $A$. spicifera remained high, while other species experienced a decrease. This presumably was due to other phycobiliprotein that provided support to metabolism process in Rhodophyceae, which also means that in terms of chlorophyll content, both species showed higher temperature tolerance than other species.

\section{Conclusion}

The most signifying results in this study showed that macroalgae from Phaeophyceae had the ability to undergo the test within a wider range of temperature exposure, while Chlorophyceae performed the worst. In terms of carbon content and chloropyll, temperature regimes of $24,27,30,33^{\circ} \mathrm{C}$ affect macroalgae from Chlorophyceae division more unequivocally than the species in other divisions. T. conoides seemed to be the most adaptive species with its ability to cope with the temperature higher than $27^{\circ} \mathrm{C}$, about which a further investigation is required in terms of physiological process.

\section{Acknowledgement}

This research has been made possible by Academic Leadership Grant of Universitas Padjadjaran in 2016.

\section{References}

B. S. Esteves, A. Taouil, and M. S. Suzuki. 2005. Nutrient Composition of Macroalgae and Macrophytes of the Açu Lagoon, Rio de Janeiro State, Brazil. Acta Limnol. Bras. 17, 233-244.

C. L. Hurd, P. J. Harrison, K. Bischof, and C. S. Lobban. 2014. Seaweed Ecology and Physiology Second Edition. (Cambridge University Press, New York), pp. 210-240.

C. M. Eakin, J. Kleypas, and O. H. Guldberg. 2008. Global Climate Change and Coral Reefs: Rising Temperatures, Acidification and the Need for Resilient Reefs In Wilkinson C. Status of Coral Reefs of the World. Townsville: Global CoralReef Monitoring Network \& Reef and Rainforest Research Centre.

D.I. Arnon. 1949. Copper Enzymes in Isolated Chloroplast, Polyphenoxidase in Beta vulgaris. Plant Physiology.. 21, 1-15.

F. Fernand, A. Israel, J. Skjermo, T. Wichard, K. R. Timmermans, A. Goldberg. 2017. Offshore Macroalgae Biomass for Bioenergy Production: Environmental Aspects, Technological Achievements and Challenges. Renew. Sust. En. Rev.. 75, 35-45.

F. Mineur, F. Arenas, J. Assis, A.J. Davies, A. H. Engelen, F. Fernandes, E. J. Malta, T. Thibaut, T. Van Nguyen, F. Paz-Vinto, S. Vranken, E. A. Serrao, O. De Clerck. 2015. European Seaweeds Under Pressure: Consequences for Communities and Ecosystem Functioning. J. Sea. Res. 98, 91-108.

J. Beardall and J. A. Raven. 2004. The Potential Effects of Global Climate Change on Microalgal Photosynthesis, Growth and Ecology. Phycologia. 43, 26-40.

I. K. Chung, J. Beardall, S. Mehta, D. Sahoo, and S. Stojkovic. 2011. Using Marine Macroalgae for Carbon Sequestration: A 
7 Omni-Akuatika Vol. 15 No. 2 Nopember $2019: 1$ - 7

Critical Appraisal. Jour. App. Phycol. 23, 877-886.

P. Kaladharan, S. Veena, and E. Vivekanandan. 2009. Carbon Sequestration by A Few Marine Algae: Observation and Projection. Journal Marine Biology Ass. India. 51, 107-110.

M. A. Monteiro. 2014. "Effects of Macroalgae Invasive Species and Temperature on Estuarine Sediments Microbial Communities and Nitrogen Biogeochemistry," Masters Thesis on Sea Sciences, University of Porto,
National Oceanic and Atmospheric Administration. International Report Confirm 2016 Was Warmest Year on Record for The Globe. Global Climate Report. (2016).

L. Porzio, M.C. Buia, M. Lorenti. A.D. Maio, and C. Arena. 2017. Physiological Response of Population of Sargassum vulgare (Phaeophyceae) to High $\mathrm{pCO} / \mathrm{low} \mathrm{pH}$ : Implications for Its Long-term Distribution. Sci. Tot. Env. 576, 917-925. 